\title{
Ecotoxicological Assessment of DNA-Tagged Silica Particles for Environmental Tracing
}

\section{Journal Article}

\section{Author(s):}

Koch, Julian; Doswald, Simon; Mikutis, Gediminas; Stark, Wendelin J.; Grass, Robert N.

Publication date:

2021-05-18

Permanent link:

https://doi.org/10.3929/ethz-b-000483016

\section{Rights / license:}

Creative Commons Attribution-NonCommercial-NoDerivatives 4.0 International

Originally published in:

Environmental Science \& Technology 55(10), https://doi.org/10.1021/acs.est.0c07968

\section{Funding acknowledgement:}

764810 - Science 4 Clean Energy (EC) 


\title{
Ecotoxicological Assessment of DNA-Tagged Silica Particles for Environmental Tracing
}

\author{
Julian Koch, Simon Doswald, Gediminas Mikutis, Wendelin J. Stark, and Robert N. Grass*
}

Cite This: Environ. Sci. Technol. 2021, 55, 6867-6875

Read Online

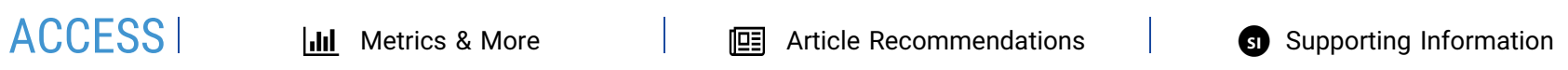

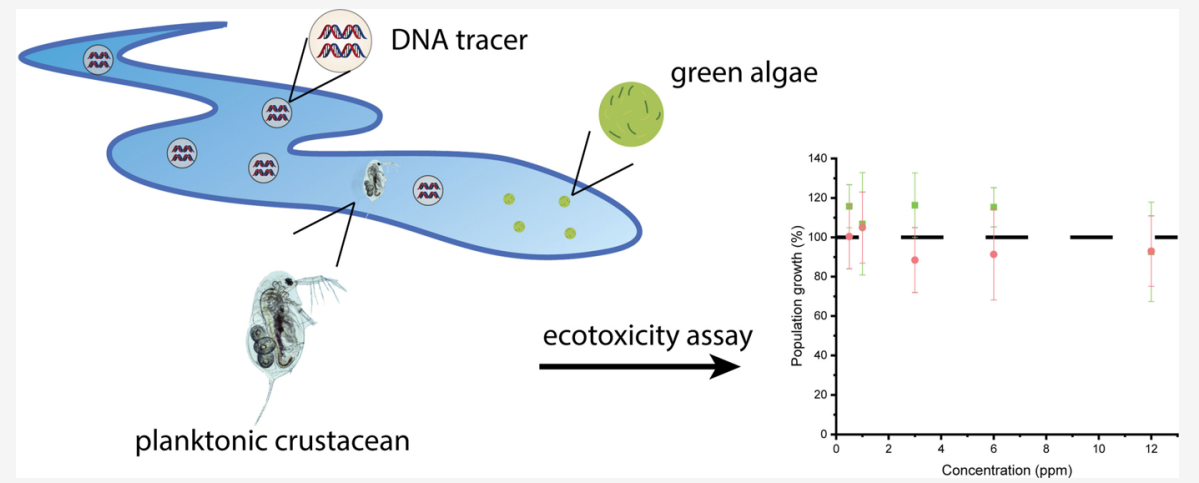

ABSTRACT: Environmental tracers are chemical species that move with a fluid and allow us to understand its origin and material transport properties. DNA-based materials have been proposed and used for tracing due to their potential for multitracing with high specificity and sensitivity. For large-scale applications of this new material it is of interest to understand its impact on the environment. We therefore assessed the ecotoxicity of sub-micron silica particles with and without encapsulated DNA in the context of surface and underground tracing of natural waterflows using standard ecotoxicity assays according to ISO standards. Acute toxicity tests were performed with Daphnia magna $(48 \mathrm{~h})$, showing no effect on mobility at tracer concentrations below 300 ppm. Chronic ecotoxicological potential was tested with Raphidocelis subcapitata (green algae) (72 h) and Ceriodaphnia species ( $7 \mathrm{~d}$ ) with no effect observed at realistic exposure scenario concentrations for both silica particles with and without encapsulated DNA. These results suggest that large-scale environmental tracing with DNA-tagged silica particles in the given exposure scenarios has a low impact on aquatic species with low trophic levels such as select algae and planktonic crustaceans.

\section{INTRODUCTION}

Understanding hydrological systems such as natural waterflow, aquifer, and groundwater reservoir connectivity is essential to improve the effectivity and decrease the environmental impact of surface and sub-surface industrial operations. ${ }^{1-3}$ Tracer experiments provide a useful tool for detection and quantification of many important parameters such as flow path, formation heterogeneity, and flow rate. The need for experimental validation has led to several other techniques (electrical resistivity imaging, ${ }^{4}$ production logging, ${ }^{5}$ and $4 \mathrm{D}$ seismic $^{6}$ ), but tracing remains an important tool for various applications, where other techniques prove difficult to apply. ${ }^{7}$ The commonly used chemical tracers include salts $(\mathrm{NaCl}$ or $\mathrm{LiBr}$ ), fluorescent dyes (uranine, rhodamine, etc.), or radioactively labeled water (high tritium content or radioactive salts). Microbial $^{8}$ or DNA-based tracers, either in solution ${ }^{9,10}$ or protected by silica encapsulation, ${ }^{11-13}$ are currently being developed to provide new opportunities for tracing applications.

An optimal tracing material has low environmental background concentration, low detection limits, and low impact on the ecosystem. Using synthetic DNA as a tracing material has many advantages. First, by choosing unique sequences of DNA, the background concentration is virtually zero. Second, DNA amplification technologies such as quantitative polymerase chain reaction (qPCR) allow us to detect down to one molecule. ${ }^{14}$ Finally, the introduced DNA is chemically identical to biological DNA, which is omnipresent in hydrological systems. ${ }^{15}$ Furthermore, the DNA sequences used in tracing can be chosen to have no biological relevance. Previous tracing studies using synthetic DNA showed that it could be detected over $1 \mathrm{~km}$ in a natural stream ${ }^{10}$ and that injecting only $36 \mu \mathrm{g}$ of DNA was sufficient to track

Received: November 25, 2020

Revised: March 15, 2021

Accepted: March 15, 2021

Published: April 26, 2021 
Table 1. Test Parameters for the Ecotoxicity Tests Used in This Work

\begin{tabular}{|c|c|c|c|}
\hline & D. magna immobilization test & algal growth inhibition test & C. dubia population growth test \\
\hline organism & D. magna Straus & $\begin{array}{l}\text { R. subcapitata (Selenastrum } \\
\text { capricornutum) }\end{array}$ & C. dubia \\
\hline test method & ISO 6341 & ISO 8692 & ISO 20665, EPA 1002.0 \\
\hline endpoint & mobility & growth & reproduction \\
\hline type of effect & acute & chronic & chronic \\
\hline temperature & $20 \pm 2{ }^{\circ} \mathrm{C}$ & $24.3 \pm 0.5^{\circ} \mathrm{C}$ & $25 \pm 1{ }^{\circ} \mathrm{C}$ \\
\hline lighting & darkness & $\begin{array}{l}\text { continuous lighting during } \\
\text { incubation }\end{array}$ & $\begin{array}{l}\text { 300-500 lux, with } 16: 8 \mathrm{~h} \text { light/dark } \\
\text { photoperiod }\end{array}$ \\
\hline test duration & $48 \mathrm{~h}$ & $72 \mathrm{~h}$ & 7 days \\
\hline measurement & immobility by eye at 24 and $48 \mathrm{~h}$ & $\begin{array}{l}\text { cell counting with Coulter } \\
\text { counter at } 72 \mathrm{~h}\end{array}$ & $\begin{array}{l}\text { organism and offspring counting at } \\
7 \text { days }\end{array}$ \\
\hline $\begin{array}{l}\text { control and dilution } \\
\text { medium }\end{array}$ & synthetic medium (ISO 6341) & synthetic medium (ISO 8692) & synthetic medium (ISO 20665) \\
\hline agitation & 然 & $\begin{array}{l}\text { continuous } \\
\text { (125 rpm, orbital shaker })\end{array}$ & none \\
\hline test design & $\begin{array}{l}5 \text { indiviuals per replicate, } 4 \text { replicates per concentration step, } \\
4 \times 5 \text { individum as control }\end{array}$ & $\begin{array}{l}3 \text { replicates per concentration, } \\
4 \text { controls }\end{array}$ & $\begin{array}{l}12 \text { replicates per concentration, } 24 \\
\text { control replicates }\end{array}$ \\
\hline test vessel & glass tubes $(15 \mathrm{~mL})$ & $\begin{array}{l}\text { polystyrene microplate } \\
(2.2 \mathrm{~mL})\end{array}$ & polypropylene beakers $(25 \mathrm{~mL})$ \\
\hline number of organisms & 5 per replicate & initial density: 1000 cell $/ \mathrm{mL}$ & 12 per concentration \\
\hline expression of results & $\mathrm{EC}_{50} 48 \mathrm{~h}$ & $\mathrm{EC}_{50} 72 \mathrm{~h}$ & $\mathrm{EC}_{50} 7$ days \\
\hline
\end{tabular}

groundwater $37 \mathrm{~m}$ after injection at 3 orders of magnitude higher than the detection limit. ${ }^{16}$

However, using DNA limits the time of tracing as it degrades within hours in natural aqueous systems. ${ }^{17,18} \mathrm{McNew}$ et al. ${ }^{19}$ proposed to encapsulate DNA with biodegradable poly-lactic acid, showing that after 5 days in water at $20^{\circ} \mathrm{C}$, the DNA tracer degraded substantially. To stabilize DNA for longer times and protect it from chemical and physical degradation, encapsulating DNA in sub-micron silica particles was presented as a viable method. ${ }^{20,21}$ Grass et al. ${ }^{22}$ exposed $\mathrm{SiO}_{2} /$ DNA particles to sewage water and showed DNA stability for at least 42 days. Mora et al. ${ }^{23}$ have shown DNA stability in various pesticide suspensions up to 76 days. The use of amorphous silica as a tracing material promises a low toxicological potential, as it can be found in high concentrations in nature ${ }^{24,25}$ and represents an important nutrient in aqueous environments. ${ }^{26}$ However, adverse effects have been found when exposing test organisms to high concentrations (>100 ppm) of sub-micron silica particles. ${ }^{27-29}$ When combining DNA and silica tracers by encapsulating DNA into silica, a system emerges, which profits from the detection limit of the DNA with the chemical integrity of the silica particles. The detection limit for silica particles tagged with DNA can be decreased down to $10^{-4} \mathrm{ppm}^{12}$ compared to $10^{1}$ to $10^{-1} \mathrm{ppm}^{30,31}$ when the particles are tagged with fluorescent markers. The low detection limit of DNA through quantification by qPCR therefore makes it a prominent tagging agent for any tracing matrix, not just silica particles, to decrease the overall exposure. In addition, by varying the DNA sequence for every batch and using bioorthogonal DNA sequences, DNA barcodes have zero environmental background concentrations. DNA-encapsulated tracers offer vastly improved detection limits and consequently lower particle loads; however, the ecological impact of these novel materials has not been evaluated yet.

The goal of this work is to assess the ecotoxicity of the $\mathrm{SiO}_{2} /$ DNA tracer material. For this, we first identified a relevant tracing scenario for a $\mathrm{SiO}_{2} / \mathrm{DNA}$ tracer to define boundary conditions for ecotoxicological assays. Then, we synthesized and characterized the silica/DNA tracer material and performed ecotoxicological tests with three different relevant organisms (Daphnia magna, Ceriodaphnia dubia, and Raphidocelis subcapitata) for aquatic ecosystems. Based on this, we will be able to estimate the impact of large-scale tracer use on an aqueous ecosystem and give recommendations on responsible tracing campaigns with this material.

\section{MATERIALS AND METHODS}

Silica/DNA Particle Synthesis. Synthesis of approximately 60, 200, and $1200 \mathrm{~nm}$ sized silica particles was based on Hartlen et al., ${ }^{32}$ Paunescu et al., ${ }^{25}$ and Wang et al., respectively, with small adaptions detailed in Text $\mathrm{S} 1$.

To produce encapsulated $\mathrm{SiO}_{2} /$ DNA particles, we based our method on a scaled up version of Paunescu et al. ${ }^{25}$ using $N$ trimethoxysilylpropyl- $N, N, N$-trimethylammonium chloride functionalized silica particles to adsorb DNA and protect it by adding a layer of silica with tetraethyl ortho silicate. The details are provided in Text S2.

Particle Characterization. The particle size in suspension was measured with a dispersion analyzer, and the surface potential was measured by a zeta potential analyzer (details in Text S3). The DNA loading per mass of particle was determined by adding buffered oxide etch (BOE) to a known particle concentration and measuring the DNA concentration by Qubit assay. For electron microscopy imaging, the particles were deposited on a graphene scanning transmission electron microscopy grid. More detailed information on particle characterization can be found in Text S3. To analyze the suspension stability of the $\mathrm{SiO}_{2} / \mathrm{DNA}$ particles, approximately $30 \mathrm{ppm}$ of particle suspension in test medium was stored stationary for up to $72 \mathrm{~h}$. At 0,24 , and 72 $h$, the samples were taken from the suspension surface and prepared for and analyzed by qPCR. Details of the method can be found in Text S4.

Particle Quantification. To release DNA from the $\mathrm{SiO}_{2} /$ DNA particle, BOE solution was prepared according to Paunescu et al. ${ }^{25}$ To $50 \mu \mathrm{L}$ of silica particle suspension, 1 $\mu \mathrm{L}$ of $\mathrm{BOE}$ was added. At a high enough particle concentration (>10 ppm), the DNA content could be measured by a Qubit fluorometer. At lower concentrations, the sample could directly 
be analyzed by qPCR without further work up. Details can be found in Text S5.

DNA Stability Tests. The DNA in $\mathrm{SiO}_{2} / \mathrm{DNA}$ particles was tested for its resistance to radical treatment according to Paunescu et al., with a combination of ascorbic acid, $\mathrm{H}_{2} \mathrm{O}_{2}$, and $\mathrm{CuCl}_{2}$ to produce reactive oxidative species and test the protective properties of $\mathrm{SiO}_{2} /$ DNA toward DNA oxidation. ${ }^{25}$ The DNA concentration was measured with a Qubit fluorometer. All experimental details can be found in Text S6.

The DNA stability was also evaluated by subjecting it to a household bleach. The bleach stock solution was prepared with $8.57 \mathrm{~mL}$ of $\mathrm{NaClO}$ (14\% activity), $1.164 \mathrm{~mL}$ of $\mathrm{NaOH} 10 \mathrm{M}$, and $30.266 \mathrm{~mL}$ of $\mathrm{H}_{2} \mathrm{O}$. A 100 -fold diluted bleach stock (143 $\mu \mathrm{L})$ was added to $143 \mu \mathrm{L}$ of DNA $(10 \mathrm{ng} / \mathrm{mL})$ or SPED suspension $(100 \mathrm{ng} / \mathrm{mL})$ and incubated for $10 \mathrm{~min}$. The reaction was quenched by adding $5 \mu \mathrm{L}$ of thiosulfate $(1.46 \mathrm{M})$. The unprotected DNA was directly measured by qPCR, whereas to the SPED samples, $6 \mu \mathrm{L}$ of BOE was added and then purified by a QIAGEN QIAquick PCR purification kit with $50 \mu \mathrm{L}$ of elution buffer. The samples were quantified by qPCR [10 $\mu \mathrm{L}$ of master mix (Roche, LightCycler 480 SYBR Green I Master Mix), $8 \mu \mathrm{L}$ of Milli-Q grade water, $1 \mu \mathrm{L}$ of primer mix [primers F0 and R0 (Microsynth AG), each at 10 $\mathrm{M}$ ], and $1 \mu \mathrm{L}$ diluted DNA pool, cycling parameters were 95 ${ }^{\circ} \mathrm{C}$ for $15 \mathrm{~s}, 54{ }^{\circ} \mathrm{C}$ for $30 \mathrm{~s}$, and $72{ }^{\circ} \mathrm{C}$ for $30 \mathrm{~s}$ for $\left.30 \mathrm{cycles}\right]$. All qPCR data reported are averaged over triplicates.

Ecotoxicological Tests. Three standard tests in the field of ecotoxicology have been used to establish the ecotoxicological profile of $\mathrm{SiO}_{2} /$ DNA tracers (Table 1). The Daphnia magna immobilization test is conventionally used to assess the shortterm acute effects of chemicals and effluents, whereas the algal growth test and the $C$. dubia test are standard protocols to evaluate chronic toxicity. All three tests were carried out (Soluval Santiago Laboratory, $\mathrm{CH}$ and EA Engineering, Science and Technology, U.S.) according to their respective standard protocols certified by ISO. In each test, the organism was exposed to a concentration range of the tracer, which allowed us to establish an $\mathrm{EC}_{X}$ value if the material had an effect in the concentration range tested. Before each medium change, the particle suspension is vortexed and treated with ultrasound. Further details can be found in Text S7.

\section{RESULTS AND DISCUSSION}

To choose relevant tracer concentrations for the ecotoxicological tests, we referred to previously performed DNA tracing experiments. A study by Mikutis et al. ${ }^{12}$ released $1 \mathrm{~L}$ with 100 ppm of the $\mathrm{SiO}_{2} /$ DNA tracer material for aquifer characterization. Similar quantities of DNA were used in a study by Foppen et al. ${ }^{9}$ but without silica as the transport and protective medium. Consequently, we consider a hypothetical point source injection with a release of $100 \mathrm{ppm}$ tracer material (Figure 1a). Scaling this to $100 \mathrm{~L}$ of $100 \mathrm{ppm}$ tracer material and considering a detection limit of $1 \mathrm{ppt},{ }^{12}$ a total volume of $10^{10} \mathrm{~L}$ of water could be traced (Figure $1 \mathrm{a}, \mathrm{b}$ ). With fluorescent silica particles, assuming a detection limit of $1 \mathrm{ppm},{ }^{31}$ only $10^{4}$ $\mathrm{L}$ water could be traced with the same amount of tracer mass. Downstream of the point injection, dilution through diffusion and convection perpendicular to the flowing motion will dilute the tracer concentration, and some tracer material may be absorbed to rocks, degrade due to the sun or air, or deviate from the main stream into smaller side streams. These effects lead to a decrease in tracer concentration to which organisms living in the concerned ecosystem will be exposed to. As a
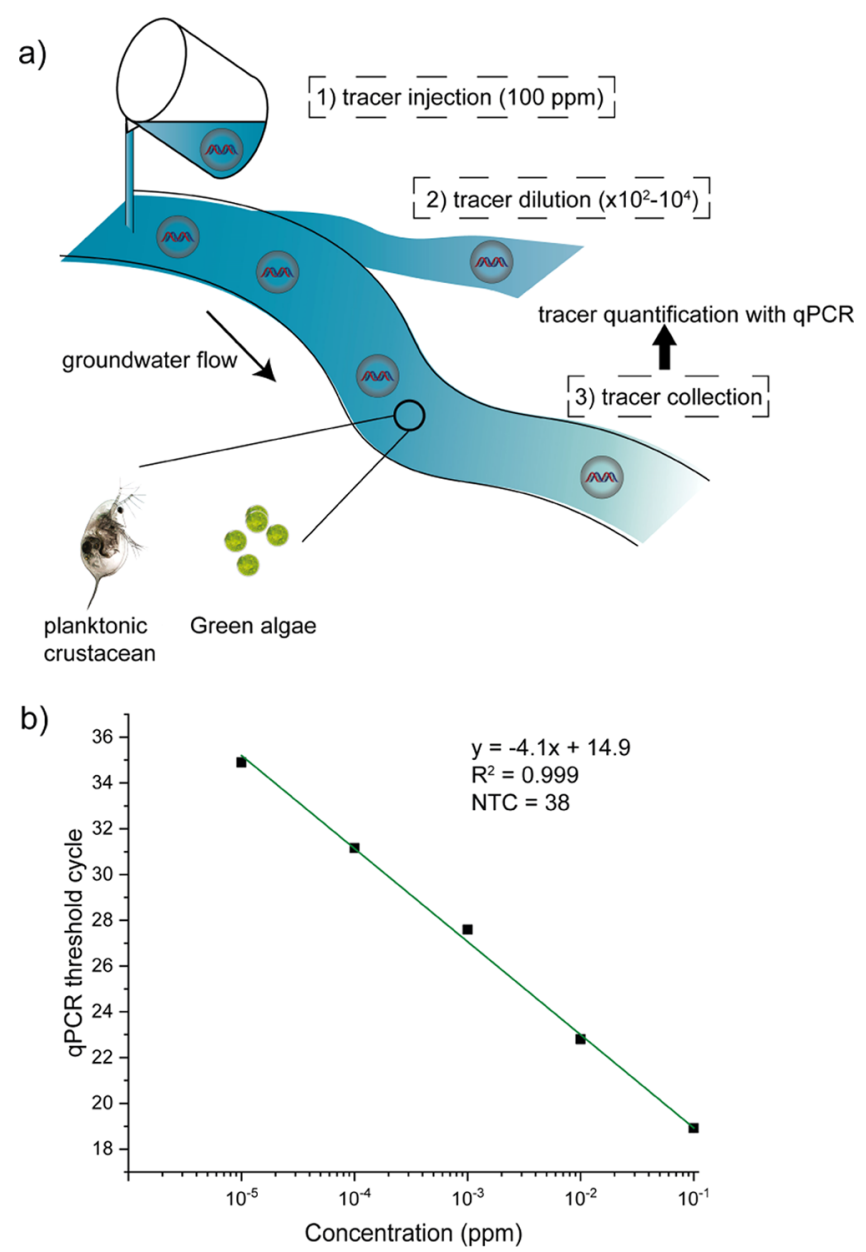

Figure 1. (a) Exposure scenario for groundwater tracing with DNA tracer technology and (b) qPCR dilution curve for particle $\mathrm{SiO}_{2}$ / DNA A. NTC = no template control.

worst-case scenario for acute exposure of an organism to the tracer over $48 \mathrm{~h}$, the initial concentration of $100 \mathrm{ppm}$ at the tracer injection point is chosen. For chronic exposure over the course of 7 days, a worst-case scenario of an upper bound of 1 $\mathrm{ppm}$ is envisioned. This estimation is based on actual tracing scenarios, ${ }^{12,34-36}$ where tracer dilution varied from $\times 10^{2}$ to $\times 10^{4}$ from start to endpoint.

To estimate the impact of the $\mathrm{SiO}_{2} / \mathrm{DNA}$ tracer material on an ecosystem, we decided to first look at each constituent material separately. The acute and chronic toxicity of synthetic amorphous silica (SAS) has been tested extensively with rodents $^{37-39}$ with no toxicity measured at up to $2000 \mathrm{mg} / \mathrm{kg}$ of SAS administered orally per day for 14 days. Genotoxic effects have not been observed with silica particles, ${ }^{29}$ whereas low cytotoxic effects have been reported at concentrations higher than $250 \mathrm{ppm}^{40}$ The acute ecotoxicity of SAS to aquatic species has been evaluated for different synthesis routes (pyrogenic, sol-gel, precipitated) $)^{27-29,40,41}$ and a range of particle sizes $(7-1000 \mathrm{~nm})$. Three studies found that at high concentrations $(>100 \mathrm{ppm})$, the uptake of particles has adverse effects toward D. magna. ${ }^{27-29}$ The decreased vitality was mainly explained by ingestion of particles, deplacing other nutritional materials or impaired mobility because of particle overloading. ${ }^{42}$ In addition, it has been hypothesized that the need for more nutrients leads to increased mobility in order to move to regions with higher nutrient availability, again 
a)

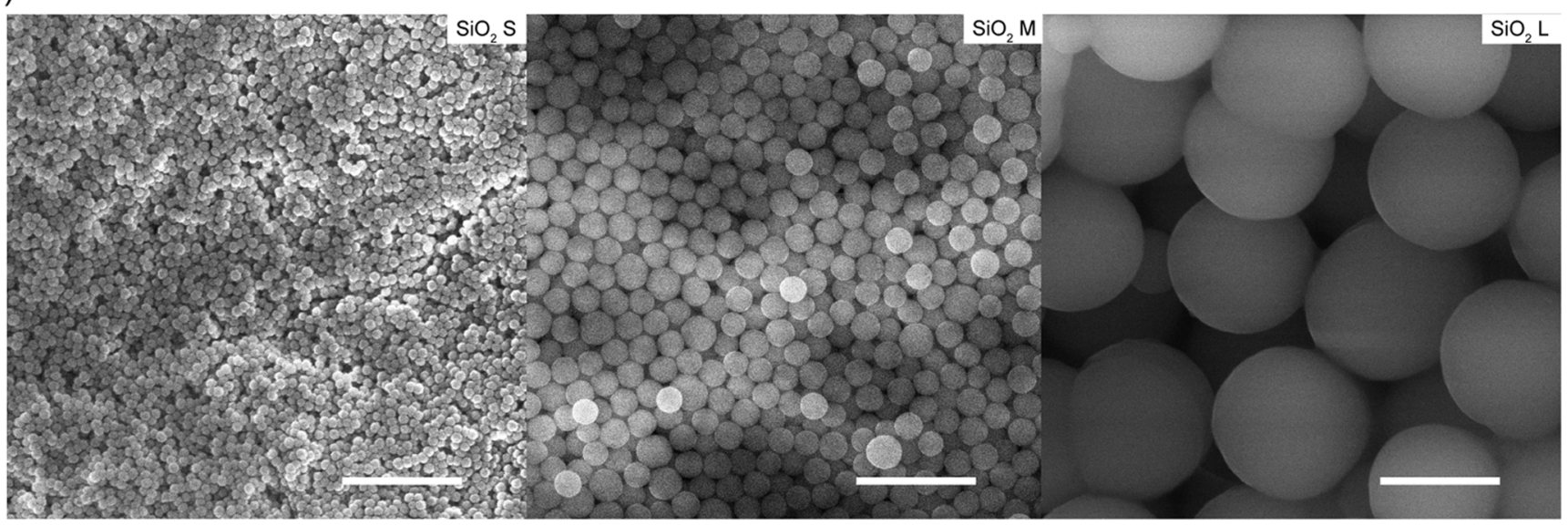

b)

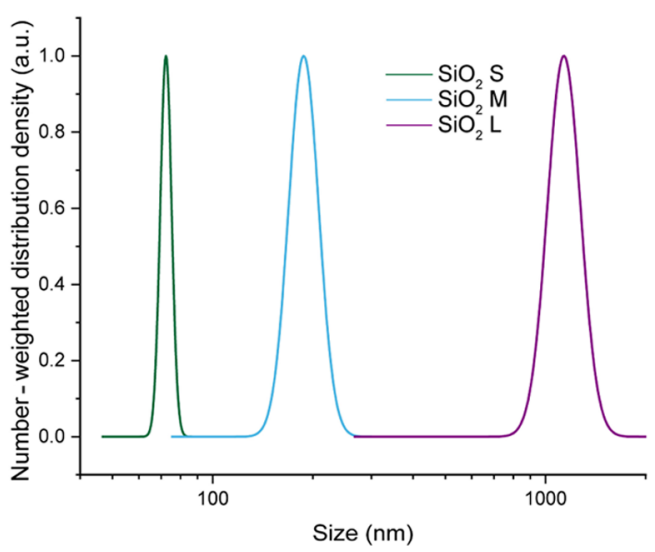

c)

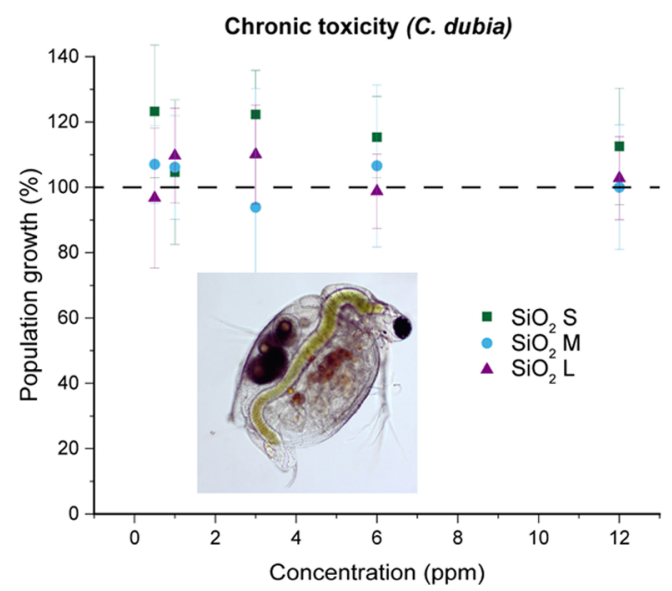

Figure 2. (a) Electron microscopy images from three silica particle batches with three different size distributions. Magnification 30,000× in all three images. Scale bar, $1 \mu \mathrm{m}$. (b) Particle size distribution measured in test medium with DLS. (c) Population growth of C. dubia after 7 days in function of silica particle concentration. Mean values and error bars (s.d.) from $n=12$ independent experiments. Image from zooplankton key Copyright 2003-2013 Center for Freshwater Biology, Department of Biological Sciences, University of New Hampshire, Durham, NH 03824, USA.

Table 2. Particle Characteristics from Six Particle Batches Used in This Study

\begin{tabular}{|c|c|c|c|c|c|c|c|}
\hline particle batch & $\begin{array}{l}\text { surface potential } \\
(\mathrm{mV})\end{array}$ & $\begin{array}{l}\text { DNA loading } \\
(\% w t)^{b}\end{array}$ & diameter $(\mathrm{nm})^{c}$ & $\begin{array}{l}\text { synthesis } \\
\text { protocol }\end{array}$ & DNA type & $\begin{array}{c}\text { DNA loss in ROS assay } \\
(\%)\end{array}$ & $\begin{array}{c}\text { DNA loss in bleach test } \\
(\%)\end{array}$ \\
\hline $\mathrm{SiO}_{2} \mathrm{~S}$ & $-38.6 \pm 1.3$ & & $66.0 \pm 23.1$ & Hartlen $^{32}$ & & & \\
\hline $\mathrm{SiO}_{2} \mathrm{M}$ & $-50.7 \pm 2.0$ & & $190.7 \pm 19.0$ & Paunescu $^{25}$ & & & \\
\hline $\mathrm{SiO}_{2} \mathrm{~L}$ & $-74.4 \pm 1.9$ & & $1136 \pm 131.0$ & Wang $^{33}$ & & & \\
\hline $\mathrm{SiO}_{2} / \mathrm{DNA} \mathrm{A}$ & $-24.2 \pm 4.2$ & 2 & $147.8 \pm 35.8$ & $1^{a}$ & barcode & 50 & 75 \\
\hline $\mathrm{SiO}_{2} /$ DNA B & $-24.5 \pm 4.5$ & 0.35 & $220.3 \pm 91.5$ & $2^{a}$ & barcode & 8 & 57 \\
\hline $\begin{array}{l}\mathrm{SiO}_{2} / \mathrm{DNA} \\
\text { Rand }\end{array}$ & $-30.8 \pm 3.1$ & 0.5 & $230.4 \pm 85.4$ & $2^{a}$ & $\begin{array}{l}\text { random } \\
\text { library }\end{array}$ & 15 & 70 \\
\hline
\end{tabular}

${ }^{a}$ Synthesis detailed in the Supporting Information. ${ }^{b}$ Measured with Qubit, see the Supporting Information. ${ }^{c}$ Measured with LumiSizer, see the Supporting Information. ${ }^{d}$ According to Paunescu et al. ${ }^{25}$; Unprotected DNA had $95 \%$ DNA loss in ROS assay. ${ }^{e}$ Unprotected DNA had $99.99 \%$ loss in bleach test.

increasing energy usage, resulting in less energy available for reproduction. ${ }^{43}$ Two studies have reported on chronic silica particle toxicity to $D$. magna at $100 \mathrm{ppm}$, showing slight morbidity $(\sim 10 \%)$ and a slightly higher reproduction rate after 21 days of exposure. ${ }^{44,45}$

For our study, we looked at another water flea, C. dubia, since its relatively fast reproduction rate allows for chronic toxicity tests over multiple generations in only 7 days (ISO 20665), while yielding comparable results with the 21-day test of D. magna. ${ }^{46}$ We decided to synthesize three different sized particle batches (Figure 2a amd Table 2) with synthesis protocols adopted from Hartlen et al. ${ }^{32}$ for small, Paunescu et al. ${ }^{25}$ for middle, and Wang et al. ${ }^{33}$ for the large sized particles. When suspending each particle batch in the test medium and measuring its size with dynamic light scattering (DLS), we found that the particle size was similar to the single particle size seen under the electron microscope (Figure 2a,b). This confirms a previous study, where no significant aggregation was found for sub-micron silica particles in a comparable test medium. ${ }^{44}$ To further understand the suspension characteristics in test medium, we measured the zeta potential (Table 2 ), indicating that the synthesized silica particles do not tend 
a)

Chronic toxicity (C. dubia)

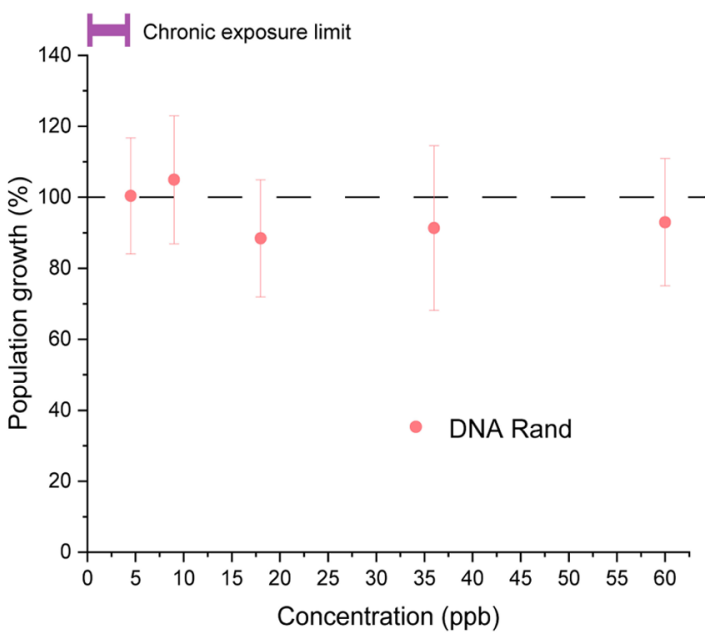

c)

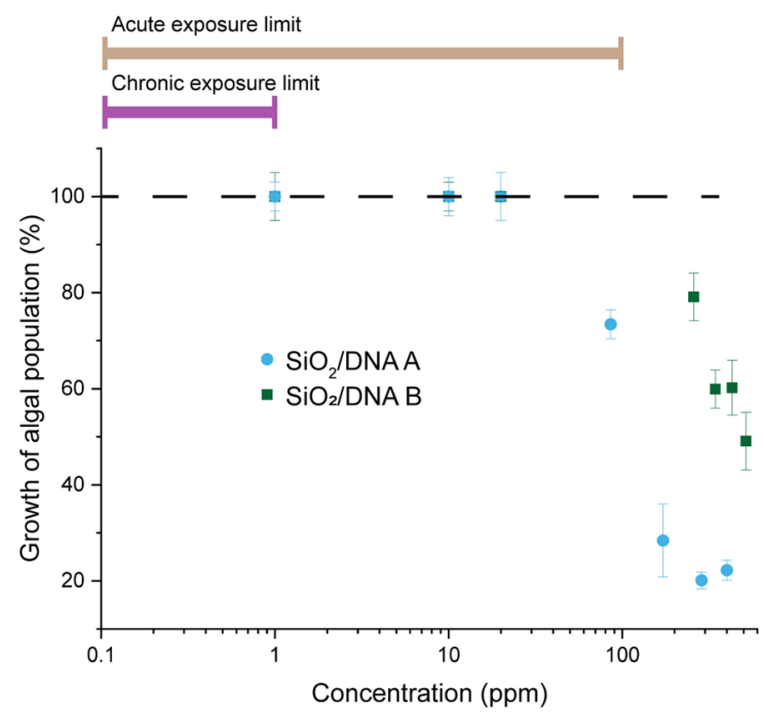

b)

Chronic toxicity (C. dubia)

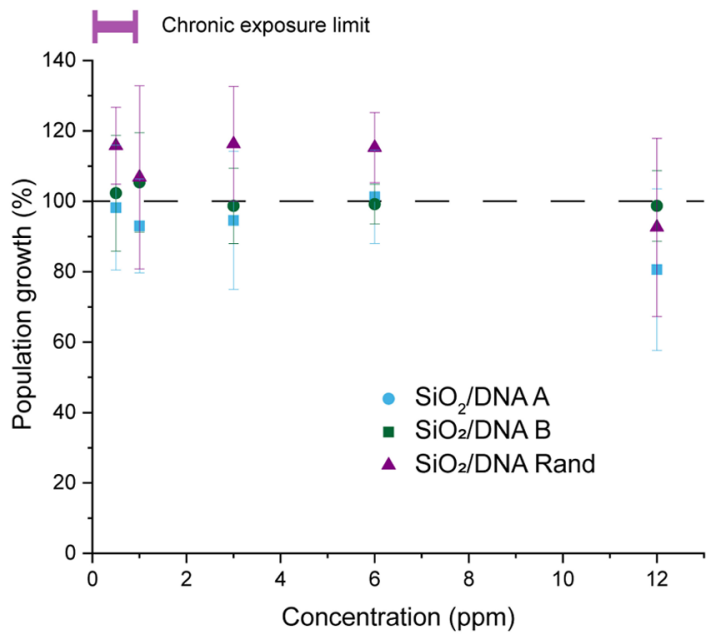

d)

Acute toxicity (D. magna)

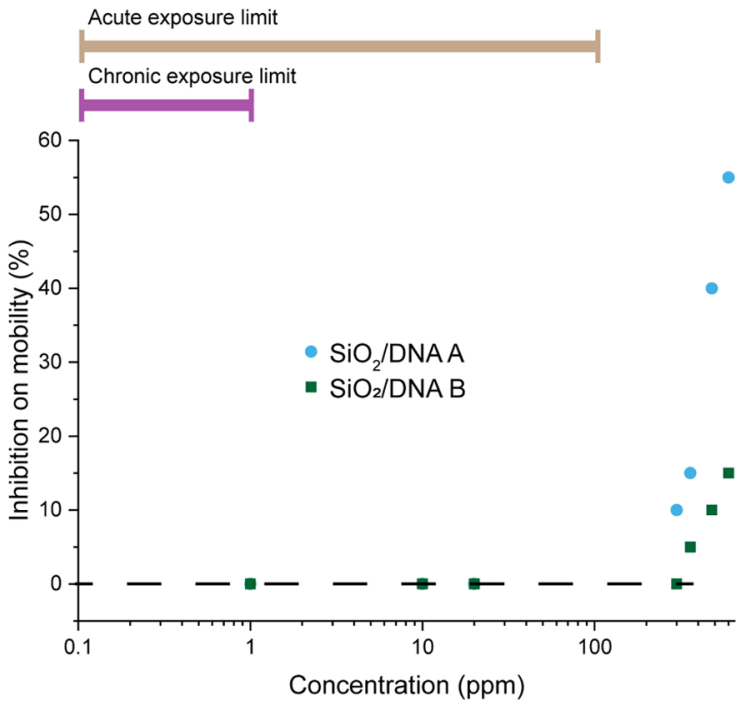

Figure 3. (a) Population growth of C. dubia after 7 days with a random DNA library. Amount of DNA corresponds to 0.5 wt $\%$ of particles. Mean values and error bars (s.d.) from $n=12$ independent experiments. (b) Population growth of C. dubia after 7 days in function of tracer concentration. Mean values and error bars (s.d.) from $n=12$ independent experiments. (c) Algal growth after $72 \mathrm{~h}$ in function of tracer concentration. Mean values and error bars (s.d.) from $n=3$ independent experiments. (d) Inhibition of mobility of $D$. magna in function of tracer concentration, estimated by eye at 24 and $48 \mathrm{~h}$. No apparent inhibition was observed at $24 \mathrm{~h}$, only results at $48 \mathrm{~h}$ are displayed.

to aggregate. To prevent any aggregation due to long-term storage, before adding the fresh test medium with suspended particles each day, the medium was vortexed and treated with ultrasound. After 7 days, no significant effect of particle concentration on population growth was found in the tested concentration range from 1 to $12 \mathrm{ppm}$ for all three particle sizes (Figure 2c). For all concentrations of $\mathrm{SiO}_{2} \mathrm{~S}$ tested, the population growth is slightly elevated compared to the control group. The higher surface area per mass of $\mathrm{SiO}_{2} \mathrm{~S}$ (size: $66 \pm$ $23.1 \mathrm{~nm}$ ) and therefore higher dissolution rate of silica could result in higher nutritional availability for the species and therefore higher population growth. Alternatively, the elevated population growth could result from stress induced by exposure to the small silica particles by prioritizing energy for reproduction rather than growth, as observed for Daphnia species when exposed to low levels of salinity. ${ }^{47}$ However, a clear correlation between population growth and particle concentration was not observed, also considering the high standard deviations for 12 replicates $( \pm 10-20 \%)$. The results of this study suggest that the exposure concentrations of silica particles in a tracing scenario for $\mathrm{SiO}_{2} \mathrm{M}$ and $\mathrm{SiO}_{2} \mathrm{~L}$ are low enough for the physical effects not to have an effect on the reproduction of these Crustacean species.

To understand if any adverse chronic effect can result from using short-sequenced synthetic double-stranded DNA (dsDNA) by itself, we exposed C. dubia to a pure DNA pool (158 base pairs) in the same 7 day exposure scenario used before. According to NIH Guidelines, ${ }^{48}$ if synthetic DNA sequences do not express for a biologically active polypeptide product, they do not fall under the framework of this guideline. Although it is unlikely that random short DNA oligos can translate for any meaningful protein (shortest reading frame is 108 nucleotides), it could be argued that DNA fragments could be incorporated into an existing genome by currently 
undiscovered mechanisms. This is however unlikely as the DNA sequences used for tracing are not designed to integrate into DNA. In both test series, no dose dependency could be observed in the concentration range tested (Figure 3a). In addition, the DNA pool used for this experiment was synthesized with a random sequence sandwiched in between constant primer regions (Table S1), indicating that the test organism was exposed to an enormous diversity of short DNA sequences, without showing any negative effects.

After studying silica particles and DNA separately, we now combined both materials to test the actual tracer material. The tracer synthesis was based on Paunescu et al., ${ }^{25}$ an established synthesis protocol for DNA/silica encapsulated particles used in studies for environmental tracing ${ }^{11,12,23}$ and other studies for food tagging ${ }^{49}$ or bacterial particle uptake. ${ }^{50}$ In short, negatively charged short-sequence dsDNA is adsorbed onto positively charged $\mathrm{SiO}_{2}$ particles because of electrostatic interactions. The exposed DNA layer is covered by an additional layer of $\mathrm{SiO}_{2}$ through Stöber synthesis, which is enough to protect the DNA from external factors such as high temperature $^{51}$ and chemical stress, ${ }^{25}$ as shown by exposing the particles to reactive oxygen species (ROS) (Table 2). In addition, free DNA and encapsulated DNA were subjected to diluted household bleach. About $99.99 \%$ of free DNA was degraded, whereas $25-43 \%$ of encapsulated DNA could be recovered. We produced two tracer batches with 65 base pair long DNA barcodes and slightly different synthesis conditions. The first, $\mathrm{SiO}_{2} / \mathrm{DNA} \mathrm{A}$, was prepared at higher particle concentration but with less coating agent added in the final step. In contrast to $\mathrm{SiO}_{2} / \mathrm{DNA} \mathrm{B}$, more coating agent was added per mass of the particle, resulting in more stable DNA when treated with ROS (Table 2). For a third particle batch, we took the same random DNA pool as described above, with the same synthesis condition as $\mathrm{SiO}_{2} / \mathrm{DNA} \mathrm{B}$. The surface potential of the finished particle was measured at $-24.2 \pm 4.2$, $-24.5 \pm 4.5$, and $-30.8 \pm 3.1 \mathrm{mV}$, respectively, and all particle sizes measured with DLS (Figure $4 \mathrm{a}$ ) are close to the single particle size determined by electron microscopy (Figure S1), indicating no major particle aggregation in suspension. Sedimentation experiments of the first two batches showed that over the course of 24 and $72 \mathrm{~h}$, the concentration of particles in still test medium was stable in the supernatant (Figure 4b). Finally, we exposed C. dubia with all three tracer batches up to $12 \mathrm{ppm}$ over 7 days and no dose-dependent toxicity was observed (Figure $3 \mathrm{~b}$ ). We observed a slightly higher average population growth at lower concentrations of $\mathrm{SiO}_{2} /$ DNA Rand compared to the control samples. However, there is no clear correlation between particle concentration and population growth, also considering the standard deviations from 12 replicates per concentration $( \pm 10-20 \%)$.

A second chronic bioassay with $R$. subcapitata was used to estimate the reproductive impact of the tracer for $72 \mathrm{~h}$ (ISO 8692). The cell density (number of cells per $\mathrm{mL}$ ) was measured with a Coulter counter in each treatment group and control. Up to $20 \mathrm{ppm}$ tracer concentrations, no effect on population growth was observed for both types (Figure 3c). For particle concentrations greater than $50 \mathrm{ppm}$, growth inhibition of algae was observed for both particle batches. The $\mathrm{EC}_{20}$ value calculated for particle $\mathrm{SiO}_{2} / \mathrm{DNA} \mathrm{A}$ was $38-77$ ppm and for particle $\mathrm{SiO}_{2} / \mathrm{DNA} B$ at 134-292 ppm. Growth inhibition on $R$. subcapitata has been reported for different types of particles at high concentrations and is associated with overloading of particles in the test organism. This can then lead a)

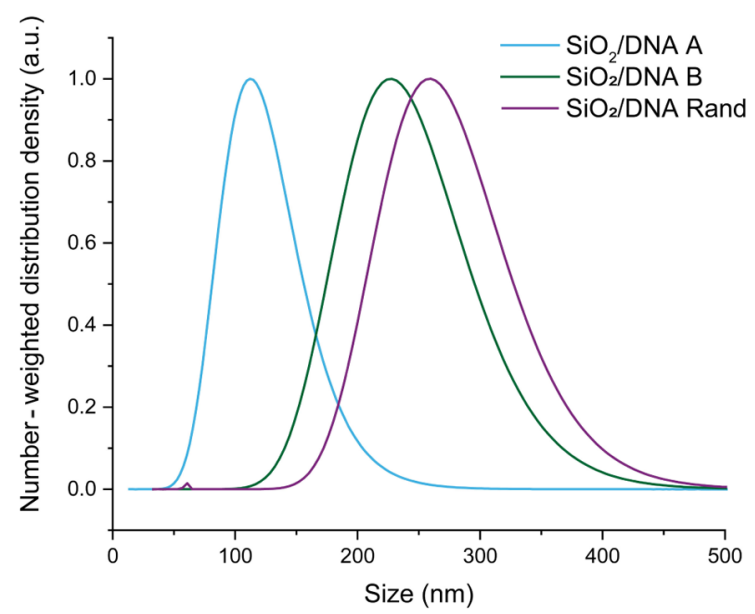

b)

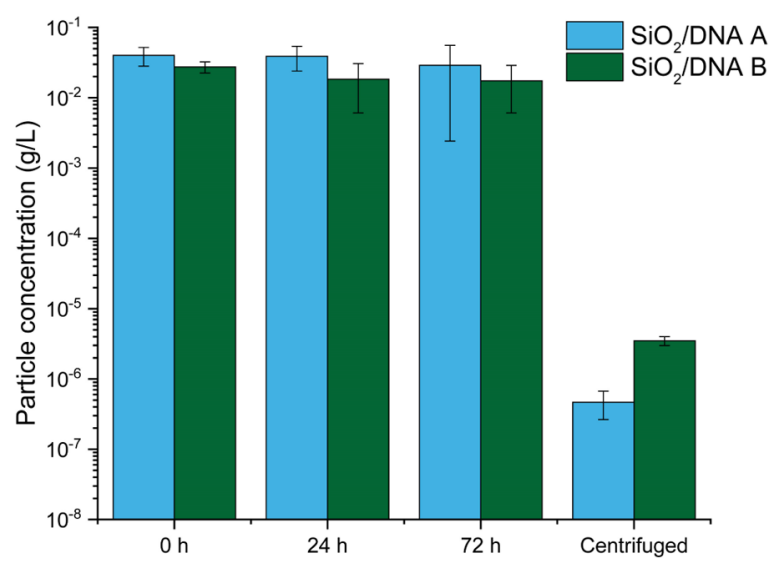

Figure 4. (a) Particle size distribution measured in test medium with DLS. (b) Supernatant particle concentration measured by qPCR at 0 , 24, and $72 \mathrm{~h}$. After $72 \mathrm{~h}$, the suspension was centrifuged and the DNA concentration in the supernatant was measured. Mean values and error bars (s.d.) from $n=3$ independent experiments.

to physical effects such as shading the algae. ${ }^{52-54}$ The increased algae sensitivity to $\mathrm{SiO}_{2} / \mathrm{DNA}$ A could therefore be explained by its smaller particle size in suspension and therefore higher surface area. Other studies have reported an $\mathrm{EC}_{20}$ after $72 \mathrm{~h}$ of $318 \mathrm{ppm}$ with a diameter of $10-40 \mathrm{~nm}^{55}$ and an $\mathrm{EC}_{20}$ after $72 \mathrm{~h}$ of 20 and $28 \mathrm{ppm}$ with particle sizes of 12.5 and $27.0 \mathrm{~nm}$, respectively. ${ }^{56}$

In contrast to the above assays for chronic toxicity, the freshwater organism D. magna was exposed to a series of tracer concentrations (ISO 6341), from 1 to $600 \mathrm{ppm}$ to assess the acute toxicity during tracer emission. In this assay, the number of daphnids, which were immobilized, was counted by eye in each treatment group and control after 24 and $48 \mathrm{~h}$. At tracer concentrations up to $20 \mathrm{ppm}$, no impact on the organism's mobility was detected for both batches (Figure 3d). At very high tracer concentrations ( $>300 \mathrm{ppm}$ ), inhibition could be observed after $48 \mathrm{~h}$. The $\mathrm{EC}_{50}$ value for $\mathrm{SiO}_{2} / \mathrm{DNA} \mathrm{B}$ was higher than the tested concentrations, whereas for $\mathrm{SiO}_{2} / \mathrm{DNA}$ $\mathrm{A}$, it was at $558 \mathrm{ppm}$. This effect at high concentrations has been seen with other types of nanoparticles $(1-100 \mathrm{~nm})$ and fine particles $(>100 \mathrm{~nm})$ and is associated with increasing collision frequency and therefore higher resistance in 
concentrated particle dispersions. ${ }^{43,57}$ Previous reports on acute toxicity of $\mathrm{SiO}_{2}$ particles for D. magna measured an $\mathrm{EC}_{50}$ of $150 \mathrm{ppm}$ for particles with a diameter from 10 to $20 \mathrm{~nm}$. ${ }^{41}$ The slightly higher effect of $\mathrm{SiO}_{2} / \mathrm{DNA} \mathrm{A}$ on the mobility compared to $\mathrm{SiO}_{2} /$ DNA B at the same concentrations could be linked to the higher surface area per mass of tracer ${ }^{56}$ resulting from the smaller particle size, thereby resulting in higher collision frequency. ${ }^{43,56}$

We have shown in this work that by using DNA as a tagging material for silica particles, we can decrease the amount of tracer material required and therefore reduce material exposure to an aqueous ecosystem. Under a realistic tracing and ecological exposure scenario, no harmful effects of the silicaencapsulated DNA tracer materials could be observed by ecotoxicological tests with D. magna and C. dubia. Using Pseudokirchneriella subcapitata (ISO 8692), a chronic $\mathrm{EC}_{20}$ of $>30 \mathrm{ppm}$ was found, and this value was further increased to

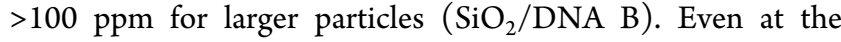
point of tracer discharge, where higher particle concentrations can be expected and physical overloading could be problematic, no acute effects on D. magna (ISO 6341) could be observed. Also, any DNA that might potentially leach from the particles during tracing experiments did not result in any chronic effects on C. dubia (ISO 20665). Consequently, and in the constraints of the chosen exposure scenario, and ecological transferability of the selected tests, the silica-encapsulated DNA tracer particles investigated in this study can be regarded as small risk to species with low trophic levels such as algae and planktonic crustaceans used routinely as model organisms for estimating the ecotoxicological impact of materials. Although no direct comparison tests are available in literature, the low detection limit and relatively high EC levels compare favorably with radioactive tracers used in the past ${ }^{58}$ and fluorescent tracers still used today. ${ }^{59,60}$

\section{ASSOCIATED CONTENT}

\section{SI Supporting Information}

The Supporting Information is available free of charge at https://pubs.acs.org/doi/10.1021/acs.est.0c07968.

Detailed particle synthesis method; particle characterization methods; particle and DNA quantification; detailed DNA stability assay; details on performed ecotoxicological assays; DNA sequences used in this work; and scanning electron microscopy images of particles (PDF)

\section{AUTHOR INFORMATION}

\section{Corresponding Author}

Robert N. Grass - Institute for Chemical and Bioengineering, ETH Zurich, 8093 Zurich, Switzerland; ㅈorcid.org/00000001-6968-0823; Phone: +41 4463363 34;

Email: robert.grass@chem.ethz.ch

\section{Authors}

Julian Koch - Institute for Chemical and Bioengineering, ETH Zurich, 8093 Zurich, Switzerland

Simon Doswald - Institute for Chemical and Bioengineering, ETH Zurich, 8093 Zurich, Switzerland

Gediminas Mikutis - Haelixa AG, 8093 Zurich, Switzerland

Wendelin J. Stark - Institute for Chemical and Bioengineering, ETH Zurich, 8093 Zurich, Switzerland; 이이.org/00000002-8957-7687
Complete contact information is available at:

https://pubs.acs.org/10.1021/acs.est.0c07968

\section{Author Contributions}

The manuscript was written through contributions of all authors. All authors have given approval to the final version of the manuscript.

\section{Notes}

The authors declare the following competing financial interest(s): RNG, WJS and GM are shareholders, GM is an employee of Haelixa AG, a company commercializing DNA tracers. All other authors declare no conflict of interest.

\section{ACKNOWLEDGMENTS}

The authors acknowledge the financial support from the Science4CleanEnergy consortium (S4CE), which is supported by the Horizon 2020 R\&D programme of the European Commission, via grant no. 764810 .

\section{REFERENCES}

(1) Harkness, J. S.; Darrah, T. H.; Warner, N. R.; Whyte, C. J.; Moore, M. T.; Millot, R.; Kloppmann, W.; Jackson, R. B.; Vengosh, A. The geochemistry of naturally occurring methane and saline groundwater in an area of unconventional shale gas development. Geochim. Cosmochim. Acta 2017, 208, 302-334.

(2) Vengosh, A.; Jackson, R. B.; Warner, N.; Darrah, T. H.; Kondash, A. A Critical Review of the Risks to Water Resources from Unconventional Shale Gas Development and Hydraulic Fracturing in the United States. Environ. Sci. Technol. 2014, 48, 8334-8348.

(3) D'Aniello, A.; Fabbricino, M.; Ducci, D.; Pianese, D. Numerical Investigation of a Methane Leakage from a Geothermal Well into a Shallow Aquifer. Groundwater 2019, 58, 598-610.

(4) Griffiths, D. H.; Barker, R. D. Two-dimensional resistivity imaging and modelling in areas of complex geology. J. Appl. Geophys. 1993, 29, 211-226.

(5) McKinley, R. M. Production Logging. International Petroleum Exhibition and Technical Symposium; Society of Petroleum Engineers, 1982.

(6) Dong, Y.; Oliver, D. S. Quantitative Use of 4D Seismic Data for Reservoir Description. SPE J. 2005, 10, 91-99.

(7) Asadi, M.; Shook, G. M. Application of Chemical Tracers in IOR: A Case History. North Africa Technical Conference and Exhibition; Society of Petroleum Engineers, 2010.

(8) Rossi, P.; Dörfliger, N.; Kennedy, K.; Müller, I.; Aragno, M. Bacteriophages as surface and ground water tracers. Hydrol. Earth Syst. Sci. 1998, 2, 101-110.

(9) Foppen, J. W.; Seopa, J.; Bakobie, N.; Bogaard, T. Development of a methodology for the application of synthetic DNA in stream tracer injection experiments. Water Resour. Res. 2013, 49, 5369-5380.

(10) Foppen, J. W.; Orup, C.; Adell, R.; Poulalion, V.; Uhlenbrook, S. Using multiple artificial DNA tracers in hydrology. Hydrol. Processes 2011, 25, 3101-3106.

(11) Liao, R.; Yang, P.; Wu, W.; Luo, D.; Yang, D. A DNA Tracer System for Hydrological Environment Investigations. Environ. Sci. Technol. 2018, 52, 1695-1703.

(12) Mikutis, G.; Deuber, C. A.; Schmid, L.; Kittilä, A.; Lobsiger, N.; Puddu, M.; Asgeirsson, D. O.; Grass, R. N.; Saar, M. O.; Stark, W. J. Silica-Encapsulated DNA-Based Tracers for Aquifer Characterization. Environ. Sci. Technol. 2018, 52, 12142-12152.

(13) Zhang, Y.; Manley, T. S.; Li, K.; Horne, R. N. Uniquely Identifiable DNA-Embedded Silica Nanotracer for Fractured Reservoir Characterization. Proceedings of the 41st Workshop on Geothermal Reservoir Engineering; Stanford University: Stanford, CA, 2016.

(14) Hindson, C. M.; Chevillet, J. R.; Briggs, H. A.; Gallichotte, E. N.; Ruf, I. K.; Hindson, B. J.; Vessella, R. L.; Tewari, M. Absolute 
quantification by droplet digital PCR versus analog real-time PCR. Nat. Methods 2013, 10, 1003-1005.

(15) Moushomi, R.; Wilgar, G.; Carvalho, G.; Creer, S.; Seymour, M. Environmental DNA size sorting and degradation experiment indicates the state of Daphnia magna mitochondrial and nuclear eDNA is subcellular. Sci. Rep. 2019, 9, 12500.

(16) Pang, L.; Robson, B.; Farkas, K.; McGill, E.; Varsani, A.; Gillot, L.; Li, J.; Abraham, P. Tracking effluent discharges in undisturbed stony soil and alluvial gravel aquifer using synthetic DNA tracers. Sci. Total Environ. 2017, 592, 144-152.

(17) Tsuji, S.; Ushio, M.; Sakurai, S.; Minamoto, T.; Yamanaka, H. Water temperature-dependent degradation of environmental DNA and its relation to bacterial abundance. PLoS One 2017, 12, No. e0176608.

(18) Halter, M. C.; Zahn, J. A. Degradation and half-life of DNA present in biomass from a genetically-modified organism during land application. J. Ind. Microbiol. Biotechnol. 2017, 44, 213-220.

(19) McNew, C. P.; Wang, C.; Walter, M. T.; Dahlke, H. E. Fabrication, detection, and analysis of DNA-labeled PLGA particles for environmental transport studies. J. Colloid Interface Sci. 2018, 526, 207-219.

(20) Grass, R. N.; Heckel, R.; Puddu, M.; Paunescu, D.; Stark, W. J. Robust Chemical Preservation of Digital Information on DNA in Silica with Error-Correcting Codes. Angew. Chem., Int. Ed. 2015, 54, 2552-2555.

(21) Paunescu, D.; Puddu, M.; Soellner, J. O. B.; Stoessel, P. R.; Grass, R. N. Reversible DNA encapsulation in silica to produce ROSresistant and heat-resistant synthetic DNA "fossils". Nat. Protoc. 2013, 8,2440 .

(22) Grass, R. N.; Schälchli, J.; Paunescu, D.; Soellner, J. O. B.; Kaegi, R.; Stark, W. J. Tracking Trace Amounts of Submicrometer Silica Particles in Wastewaters and Activated Sludge Using SilicaEncapsulated DNA Barcodes. Environ. Sci. Technol. Lett. 2014, 1, 484-489.

(23) Mora, C. A.; Schärer, H.-J.; Oberhänsli, T.; Ludwig, M.; Stettler, R.; Stoessel, P. R.; Grass, R. N.; Stark, W. J. Ultrasensitive Quantification of Pesticide Contamination and Drift Using Silica Particles with Encapsulated DNA. Environ. Sci. Technol. Lett. 2016, 3, $19-23$.

(24) Johnson, T. C.; Eisenreich, S. J. Silica in Lake Superior: mass balance considerations and a model for dynamic response to eutrophication. Geochim. Cosmochim. Acta 1979, 43, 77-92.

(25) Paunescu, D.; Puddu, M.; Soellner, J. O. B.; Stoessel, P. R.; Grass, R. N. Reversible DNA encapsulation in silica to produce ROSresistant and heat-resistant synthetic DNA "fossils". Nat. Protoc. 2013, $8,2440-2448$.

(26) DeMaster, D. J. The supply and accumulation of silica in the marine environment. Geochim. Cosmochim. Acta 1981, 45, 1715.

(27) Adams, L. K.; Lyon, D. Y.; McIntosh, A.; Alvarez, P. J. J. Comparative toxicity of nano-scale $\mathrm{TiO} 2, \mathrm{SiO} 2$ and $\mathrm{ZnO}$ water suspensions. Water Sci. Technol. 2006, 54, 327-334.

(28) Han, B.; Wei, C.; Yang, D.; Hu, C.; Yu, X.; Yang, X. Acute Toxicity of Suspension of Nanosized Silicon Dioxide Particles to Daphnia magna. 3rd International Conference on Bioinformatics and Biomedical Engineering, 2009.

(29) Lee, S.-W.; Kim, S.-M.; Choi, J. Genotoxicity and ecotoxicity assays using the freshwater crustacean Daphnia magna and the larva of the aquatic midge Chironomus riparius to screen the ecological risks of nanoparticle exposure. Environ. Toxicol. Pharmacol. 2009, 28, 8691.

(30) Alaskar, M.; Li, K.; Horne, R. Silica Particles Mobility Through Fractured Rock. Arabian J. Sci. Eng. 2015, 40, 1205-1222.

(31) Yoon, Y.; Lueptow, R. M. Concentration of colloidal silica suspensions using fluorescence spectroscopy. Colloids Surf., A 2006, 277, 107-110.

(32) Hartlen, K. D.; Athanasopoulos, A. P. T.; Kitaev, V. Facile Preparation of Highly Monodisperse Small Silica Spheres (15 to >200 $\mathrm{nm}$ ) Suitable for Colloidal Templating and Formation of Ordered Arrays. Langmuir 2008, 24, 1714-1720.
(33) Wang, X.-D.; Shen, Z.-X.; Sang, T.; Cheng, X.-B.; Li, M.-F.; Chen, L.-Y.; Wang, Z.-S. Preparation of spherical silica particles by Stöber process with high concentration of tetra-ethyl-orthosilicate. J. Colloid Interface Sci. 2010, 341, 23-29.

(34) Capesius, J. P.; Sullivan, J. R.; O’Neill, G. B.; Williams, C. A.; Norton, G. A.; Survey, U. S. G. Using the Tracer-Dilution Discharge Method to Develop Streamflow Records for Ice-Affected Streams in Colorado; U.S. Geological Survey, 2005, Scientific Investigations Report 2004-5164.

(35) Davis, S. N.; Thompson, G. M.; Bentley, H. W.; Stiles, G. Ground-Water Tracers-A Short Review. Groundwater 1980, 18, 1423

(36) Zellweger, G. W.; Avanzino, R. J.; Bencala, K. E. Comparison of Tracer-Dilution and Current-Meter Discharge Measurements in a Small Gravel-Bed Stream, Little Lost Man Creek, California; U.S. Geological Survey, 1989, Water-Resources Investigations Report.

(37) Sayes, C. M.; Reed, K. L.; Glover, K. P.; Swain, K. A.; Ostraat, M. L.; Donner, E. M.; Warheit, D. B. Changing the dose metric for inhalation toxicity studies: Short-term study in rats with engineered aerosolized amorphous silica nanoparticles. Inhalation Toxicol. 2010, $22,348-354$

(38) Kim, Y.-R.; Lee, S.-Y.; Lee, E. J.; Park, S. H.; Seong, N.-W.; Seo, H.-S.; Shin, S.-S.; Kim, S.-J.; Meang, E.-H.; Park, M.-K.; Kim, M.-S.; Kim, C.-S.; Kim, S.-K.; Son, S. W.; Seo, Y. R.; Kang, B. H.; Han, B. S.; An, S. S. A.; Lee, B.-J.; Kim, M.-K. Toxicity of colloidal silica nanoparticles administered orally for 90 days in rats. Int. J. Nanomed. 2014, 9, 67-78.

(39) Tarantini, A.; Huet, S.; Jarry, G.; Lanceleur, R.; Poul, M.; Tavares, A.; Vital, N.; Louro, H.; João Silva, M.; Fessard, V. Genotoxicity of synthetic amorphous silica nanoparticles in rats following short-term exposure. Part 1: Oral route. Environ. Mol. Mutagen. 2015, 56, 218-227.

(40) Casado, M. P.; Macken, A.; Byrne, H. J. Ecotoxicological assessment of silica and polystyrene nanoparticles assessed by a multitrophic test battery. Environ. Int. 2013, 51, 97-105.

(41) Yang, S.; Ye, R.; Han, B.; Wei, C.; Yang, X. Ecotoxicological Effect of Nano-silicon Dioxide Particles on Daphnia Magna. Integr. Ferroelectr. 2014, 154, 64-72.

(42) Artells, E.; Issartel, J.; Auffan, M.; Borschneck, D.; Thill, A.; Tella, M.; Brousset, L.; Rose, J.; Bottero, J.-Y.; Thiéry, A. Exposure to cerium dioxide nanoparticles differently affect swimming performance and survival in two daphnid species. PLoS One 2013, 8, No. e71260.

(43) Skjolding, L. M.; Sørensen, S. N.; Hartmann, N. B.; Hjorth, R.; Hansen, S. F.; Baun, A. Aquatic Ecotoxicity Testing of NanoparticlesThe Quest To Disclose Nanoparticle Effects. Angew. Chem., Int. Ed. 2016, 55, 15224-15239.

(44) Karimi, S.; Troeung, M.; Wang, R.; Draper, R.; Pantano, P. Acute and chronic toxicity of metal oxide nanoparticles in chemical mechanical planarization slurries with Daphnia magna. Environ. Sci.: Nano 2018, 5, 1670-1684.

(45) Lillicrap, A.; Allan, I.; Friede, B.; Garmo, Ø.; Macken, A. Is the transformation/dissolution protocol suitable for ecotoxicity assessments of inorganic substances such as silica fume? Sci. Total Environ. 2014, 468-469, 358-367.

(46) Versteeg, D. J.; Stalmans, M.; Dyer, S. D.; Janssen, C. Ceriodaphnia and Daphnia: A comparison of their sensitivity to xenobiotics and utility as a test species. Chemosphere 1997, 34, 869892.

(47) Venâncio, C.; Castro, B. B.; Ribeiro, R.; Antunes, S. C.; Abrantes, N.; Soares, A. M. V. M.; Lopes, I. Sensitivity of freshwater species under single and multigenerational exposure to seawater intrusion. Philos. Trans. R. Soc., B 2019, 374, 20180252.

(48) NIH. Biosafety and Recombinant DNA Policy; NIH Office of Science Policy, 2019.

(49) Bloch, M. S.; Paunescu, D.; Stoessel, P. R.; Mora, C. A.; Stark, W. J.; Grass, R. N. Labeling Milk along Its Production Chain with DNA Encapsulated in Silica. J. Agric. Food Chem. 2014, 62, 1061510620. 
(50) Hoop, M.; Paunescu, D.; Stoessel, P. R.; Eichenseher, F.; Stark, W. J.; Grass, R. N. PCR quantification of $\mathrm{SiO} 2$ particle uptake in cells in the ppb and ppm range via silica encapsulated DNA barcodes. Chem. Commun. 2014, 50, 10707-10709.

(51) Paunescu, D.; Fuhrer, R.; Grass, R. N. Protection and Deprotection of DNA-High-Temperature Stability of Nucleic Acid Barcodes for Polymer Labeling. Angew. Chem., Int. Ed. 2013, 52, $4269-4272$.

(52) Sørensen, S. N.; Engelbrekt, C.; Lützhøft, H.-C. H.; JiménezLamana, J.; Noori, J. S.; Alatraktchi, F. A.; Delgado, C. G.; Slaveykova, V. I.; Baun, A. A Multimethod Approach for Investigating Algal Toxicity of Platinum Nanoparticles. Environ. Sci. Technol. 2016, 50, $10635-10643$.

(53) Hartmann, N. B.; Engelbrekt, C.; Zhang, J.; Ulstrup, J.; Kusk, K. O.; Baun, A. The challenges of testing metal and metal oxide nanoparticles in algal bioassays: titanium dioxide and gold nanoparticles as case studies. Nanotoxicology 2012, 7, 1082-1094.

(54) Hartmann, N. B.; Von der Kammer, F.; Hofmann, T.; Baalousha, M.; Ottofuelling, S.; Baun, A. Algal testing of titanium dioxide nanoparticles-Testing considerations, inhibitory effects and modification of cadmium bioavailability. Toxicology 2010, 269, 190197.

(55) Metzler, D. M.; Erdem, A.; Tseng, Y. H.; Huang, C. P. Responses of Algal Cells to Engineered Nanoparticles Measured as Algal Cell Population, Chlorophyll a, and Lipid Peroxidation: Effect of Particle Size and Type. Nanotechnology 2012, 2012, 1-12.

(56) Van Hoecke, K.; De Schamphelaere, K. A. C.; Van der Meeren, P.; Lucas, S.; Janssen, C. R. Ecotoxicity of silica nanoparticles to the green alga Pseudokirchneriella subcapitata: Importance of surface area. Environ. Toxicol. Chem. 2008, 27, 1948-1957.

(57) Handy, R. D.; von der Kammer, F.; Lead, J. R.; Hassellöv, M.; Owen, R.; Crane, M. The ecotoxicology and chemistry of manufactured nanoparticles. Ecotoxicology 2008, 17, 287-314.

(58) IAEA. Use of Radiotracers to Study Surface Water Processes, IAEA-TECDOC-1760, 2015.

(59) Walthall, W. K.; Stark, J. D. The acute and chronic toxicity of two xanthene dyes, fluorescein sodium salt and phloxine $B$, to Daphnia pulex. Environ. Pollut. 1999, 104, 207-215.

(60) Rowiński, P. M.; Chrzanowski, M. M. Influence of selected fluorescent dyes on small aquatic organisms. Acta Geophys. 2011, 59, 91-109. 